\title{
Geological and Geotechnical Characteristics of London Clay from the Isle of Sheppey
}

\author{
Meghdad Bagheri • Mohammad Rezania
}

Received: 13 January 2020/Accepted: 16 September 2020/Published online: 25 September 2020

(C) The Author(s) 2020

\begin{tabular}{|c|c|c|}
\hline \multirow{9}{*}{$\begin{array}{l}\text { Abstract The paper describes a series of experi- } \\
\text { mental testing on natural stiff London clay samples } \\
\text { retrieved from the New Hook Farm in the Isle of } \\
\text { Sheppey, UK. The experimental program includes } \\
\text { determination of macroscopic and microscopic prop- } \\
\text { erties, chemical compositions, Atterberg limits, per- } \\
\text { meability, and compressibility parameters in both } \\
\text { intact and reconstituted states. The paper integrates the } \\
\text { earlier studies, the new findings, and the commercial } \\
\text { investigation results with the aim to extend the current } \\
\text { knowledge of the geological and geotechnical char- } \\
\text { acteristics of this stiff clay from the east of the London } \\
\text { basin. Some comparisons are also made with shallow } \\
\text { depth London clay from Heathrow Terminal } 5 \text { site. }\end{array}$} & $C_{s}$ & Swelling index \\
\hline & $C_{\alpha}$ & Creep index \\
\hline & $D$ & Particle diameter \\
\hline & $D_{10}$ & $\begin{array}{l}\text { The intercept for } 10 \% \text { cumulative mass on } \\
\text { PSD curve }\end{array}$ \\
\hline & $D_{25}$ & $\begin{array}{l}\text { The intercept for } 25 \% \text { cumulative mass on } \\
\text { PSD curve }\end{array}$ \\
\hline & $D_{50}$ & $\begin{array}{l}\text { The intercept for } 50 \% \text { cumulative mass on } \\
\text { PSD curve }\end{array}$ \\
\hline & $D_{75}$ & $\begin{array}{l}\text { The intercept for } 75 \% \text { cumulative mass on } \\
\text { PSD curve }\end{array}$ \\
\hline & $D_{90}$ & $\begin{array}{l}\text { The intercept for } 90 \% \text { cumulative mass on } \\
\text { PSD curve }\end{array}$ \\
\hline & $e$ & Void ratio \\
\hline & $e_{0}$ & Initial void ratio \\
\hline Keywords Clays $\cdot$ Compressibility $\cdot$ Grain size & $G_{s}$ & Specific gravity \\
\hline analysis $\cdot$ Microstructure & $i$ & Hydraulic conductivity \\
\hline & $I_{p}$ & Plasticity index \\
\hline List of Symbols & $k_{v}$ & COEFFICIENT of vertical permeability \\
\hline A Specimen cross section area & $p^{\prime}$ & Mean effective stress \\
\hline$C_{c} \quad$ Compression index & $\begin{array}{l}p_{c} \\
Q\end{array}$ & $\begin{array}{l}\text { Pressure loss in the specimen } \\
\text { Mean rate of flow of water through the soil } \\
\text { specimen }\end{array}$ \\
\hline $\begin{array}{l}\text { M. Bagheri } \\
\text { School of Energy, Construction and Environment, } \\
\text { Coventry University, Coventry, UK } \\
\text { e-mail: meghdad.bagheri@ @oventry.ac.uk }\end{array}$ & $\begin{array}{l}q / p^{\prime} \\
q \\
R_{t}\end{array}$ & $\begin{array}{l}\text { Stress ratio } \\
\text { Deviatoric stress } \\
\text { Temperature correction factor for the } \\
\text { viscosity of water }\end{array}$ \\
\hline $\begin{array}{l}\text { M. Rezania }(\bowtie) \\
\text { School of Engineering, University of Warwick, Coventry, } \\
\text { UK }\end{array}$ & $\begin{array}{l}S_{0} \\
w_{0} \\
w_{L}\end{array}$ & $\begin{array}{l}\text { Initial suction } \\
\text { Initial gravimetric water content } \\
\text { Liquid limit }\end{array}$ \\
\hline
\end{tabular}




$\begin{array}{ll}w_{P} & \text { Plastic limit } \\ \alpha & \text { Represents the ratio } \mathrm{C}_{\alpha} / \mathrm{C}_{c} \\ \rho_{b} & \text { Initial bulk density } \\ \sigma_{p} & \text { Yield vertical net stress } \\ \sigma^{\prime}{ }_{v} & \text { Vertical effective stress } \\ \sigma_{v n e t} & \text { Vertical net stress } \\ \varepsilon_{a} & \text { Axial strain } \\ \text { ESEM } & \text { Environmental Scanning Electron } \\ & \text { Microscope } \\ \text { EDX } & \text { Energy dispersive X-ray } \\ \text { LC } & \text { London clay } \\ \text { MCV } & \text { Moisture condition value } \\ \text { PSD } & \text { Particle size distribution } \\ \text { QD } & \text { Queensborough clay } \\ \text { SWRC } & \text { Soil water retention curve } \\ \text { T5 } & \text { Terminal 5 site } \\ \text { TDS } & \text { Total dissolved solids } \\ \text { WAC } & \text { Waste acceptance criteria }\end{array}$

\section{Introduction}

Since 1960s, the Isle of Sheppey along with the Isle of Grain, Cliffe, and Foulness Island have been labelled as potential sites for construction of a new airport as an alternative to the Heathrow airport to reduce the aircraft noise pollution in south east of England (Helsey and Codd 2014). The proposals of new airport in the Isle of Sheppey, the birthplace of British aviation, although rejected several times by the Department for Transport, implies the significance of this site which may in future be considered for wider infrastructure investments and developments. The ground profile of the Isle of Sheppey consists of deep London clay (LC) deposits. Very few works can be found in the literature on characterisation of the Sheppey LC (e.g. Burnett and Fookes 1974; Huggett 1994), despite the necessity for developing a clear understanding of the geological and hydro-mechanical properties of this soil. In one of the few studies on Sheppey soils, Jardine et al. (2003) reported characterisation of a soft peaty clay deposit found at the Queenborough bypass viaduct site on the north of the Isle of Sheppey. This temperate estuarine marsh clay is known as Queensborough clay (QC) and has been the subject of several studies (e.g. Smith 1992). The QC was reported to be mixed with material from surrounding LC hills and cliffs as a result of mass movement and sea erosion (Jardine et al. 2003). The reconstituted QC was found to have identical Atterberg limits, grading curve, and intrinsic compression parameters to the reconstituted LC samples investigated and reported by Jardine (1985). Hence, still there appears to be a lack of technical knowledge on characteristics of the Sheppey LC. An experimental program was, therefore, devised to fill this gap and add valuable information to the existing database. Undisturbed block samples of $350 \mathrm{~mm}$ cube were taken at $4 \mathrm{~m}$ depth below non-quarried ground level at New Hook farm reservoir site located on the outskirts of Sheerness town on the Isle of Sheppey. This site is owned by SW Attwood \& Partners Ltd. The principal operation of the site is a fishing pond and water reservoir and at the time of sampling, it was in its initial stages of excavation. Figure 1 presents the site map and location of block sampling.

Commercial laboratory testing was carried out by CET Structures Ltd and included contamination analysis, permeability and in-situ water content measurements. Preliminary laboratory testing for microstructural analysis and determination of the index properties, chemical composition, and onedimensional compressibility were carried out at the University of Nottingham and The University of Warwick. The obtained results are compared with the corresponding characteristics of the shallow depth LC from Terminal 5 (T5) site at Heathrow airport, reported in the literature.

\section{The Sheppey Member}

King (1981) studied the biostratigraphy and lithological variations of LC formation and suggested a division of the formation into five principal units, named Divisions A to E. These divisions are subdivided into several members within the LC formation, named as; Walton, Claygate, Ockendon, Aveley, Sheppey, and Bracknell Members. The LC formation in Sheppey cliffs, Isle of Sheppey, which exposes the upper part of the LC formation is named Sheppey Member and corresponds approximately to the upper part of Division C, Division D and most of Division E (King 1981). The thickness of the Sheppey Member is approximately $55 \mathrm{~m}$ and is classified as Thames Group. According to Aldiss (2014), the Sheppey 
Fig. 1 Site map and sampling locations in New Hook farm
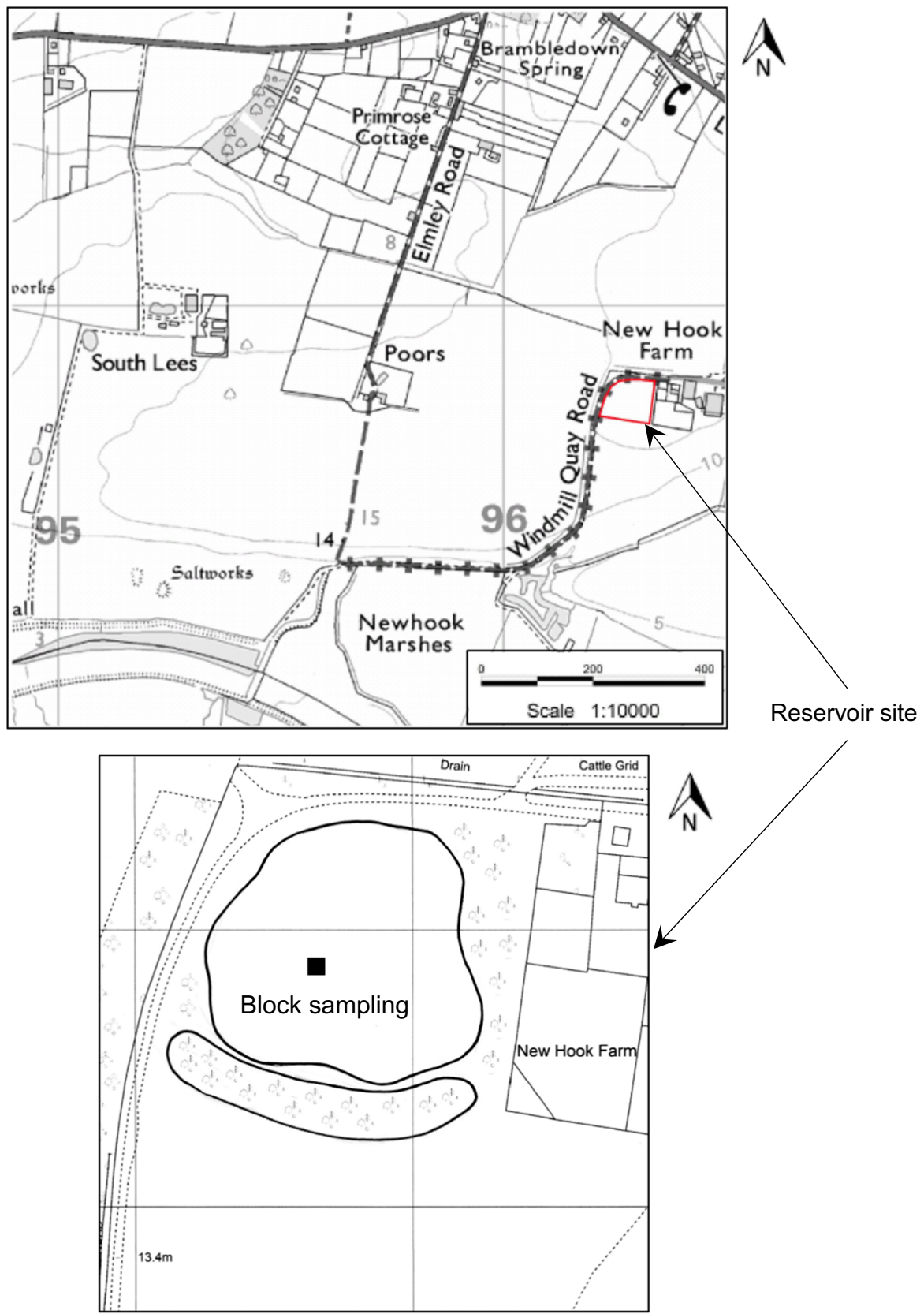

Member mainly comprises silty clay diffusely interbedded with sandy clayey silt and contains several layers of calcareous concretions.

Burnett and Fookes (1974) reported that the Sheppey LC comprises of $58 \%$ of particles $<2 \mu \mathrm{m}$ size and $42 \%$ particles $>2 \mu \mathrm{m}$ size. The particles $<2 \mu \mathrm{m}$ size were approximately $90 \%$ clay minerals which were found to comprise $57 \%$ montmorillonite (a member of smectite group), $24 \%$ illite, $12 \%$ kaolinite, and $7 \%$ chlorite. The particles $>2 \mu \mathrm{m}$ size were mainly silt which was found to comprise $70 \%$ quartz carbonates, $15 \%$ pyrite, and $15 \%$ clay minerals. Similar compositions were reported by Gasparre (2005) for Unit C (7 m depth) T5 LC, which comprises $53 \%$ of particles $<2 \mu \mathrm{m}$ size formed mainly of $60 \%$ 
illite-smectite, $22 \%$ illite, $15 \%$ kaolinite, and $4 \%$ chlorite.

\section{Macro-Fabric and Microstructure}

The macro-fabric of LC is characterised by the presence of discontinuities which play a significant role in its mechanical behaviour (Burland 1990; Hight and Jardine 1993; Hight et al. 2003). These discontinuities are in the form of fissures, joints (or backs), bedding surfaces (or laminations), tectonic shear surfaces, recently formed shear surfaces, and minor faults (Skempton et al. 1969; Hight et al. 2003). Figure 2 depicts the fissured and jointed pattern of the LC at shallow depth at New Hook farm and T5 sites. The occurrence of fissures was reported to be the dominant feature of the block samples retrieved from Unit C (7 m depth) at T5 site (Gasparre 2005).

The brown, brownish grey, or mottled brown and grey coloured LC, typically found in the top 5-10 m depths, has been recognised as weathered LC (colour changes from blue-grey to brown) and contains selenite crystals, a form of gypsum-hydrated calcium sulphate (Hight et al. 1993; Aldiss 2014). Figure 3 shows the presence of selenite crystals in retrieved samples from New Hook farm.

To identify the basic structural properties (soil fabric) and chemical composition of the retrieved samples, a microstructure and mineralogy analysis was carried out using a Philips XL30 FEG environmental scanning electron microscope (ESEM) equipped with an Energy Dispersive X-ray (EDX) analyser. For ESEM analysis, cubic subsamples of approximately $1 \mathrm{~cm}^{3}$ size were excavated from the central portions of the intact samples.

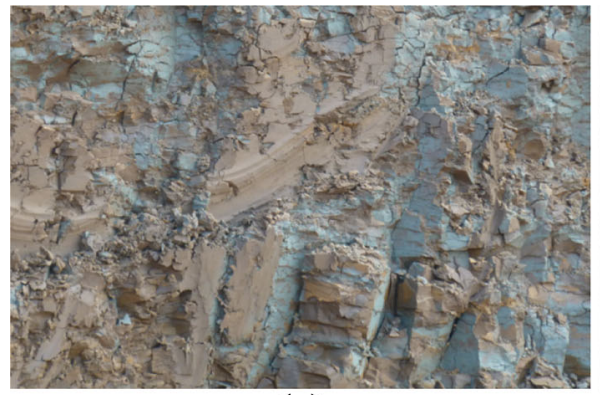

(a)

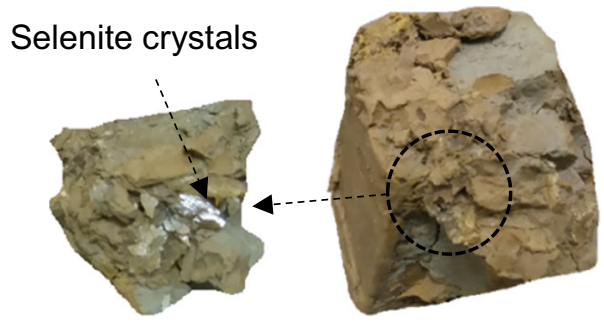

Fig. 3 Selenite crystals found in retrieved samples

The micrographs of Figs. 4 and 5 reveal the large proportions of randomly oriented silt with irregular angular fine sand-sized grains and calcite crystals imbedded in the clay matrix.

The clay structure appears to be flocculated and composed of proportionally equal large flocs and single plate-shaped particles with edge-to-edge, edge-to-face and face-to-face contacts (Fig. 6). As can be seen, the edge-to-edge contacts of the clay domains have resulted in development of large pores in the clay cluster. This soil fabric is comparable with flocculated cardhouse fabric reported by Gasparre (2005) for T5 LC at shallow depths. The micrograph of Fig. 7 depicts a pyrite particle surrounded by clay domains and single particles.

Figure 8 shows the steps of drying a flooded specimen in the ESEM. As can be seen, the drying process does not noticeably affect the macrostructure and arrangement of the clay flocs. Also shown in the figure, is the removal of the water menisci developed at inter-floc pores (throats) during sequential drying of the specimen.

\section{Chemical Composition}

The diagenesis analysis carried out by Huggett (1994) on LC samples recovered from Warden Point on the

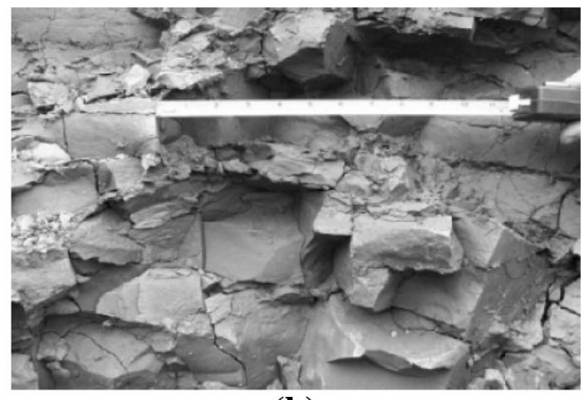

(b)

Fig. 2 Fissured pattern at: a shallow depth at New Hook farm reservoir site; b shallow depth at T5 site (Hight et al. 2007) 


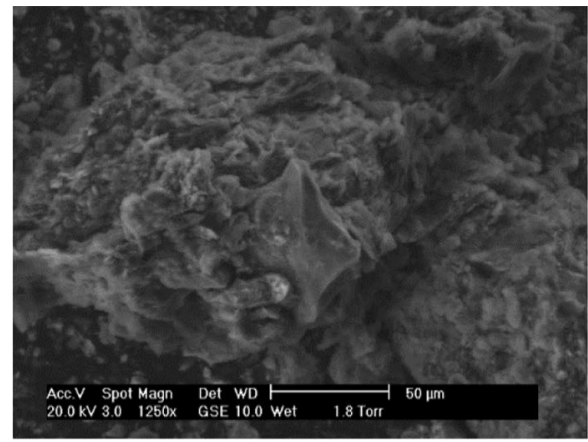

(a)

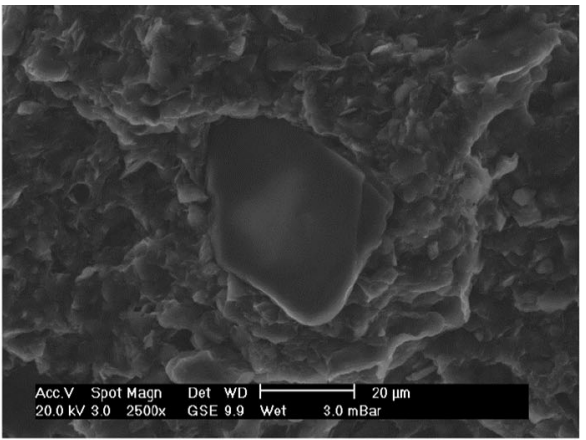

(b)

Fig. 4 ESEM micrographs showing the coarser-grained particles imbedded in the clay matrix at magnification of: a 1250x, b 2500x

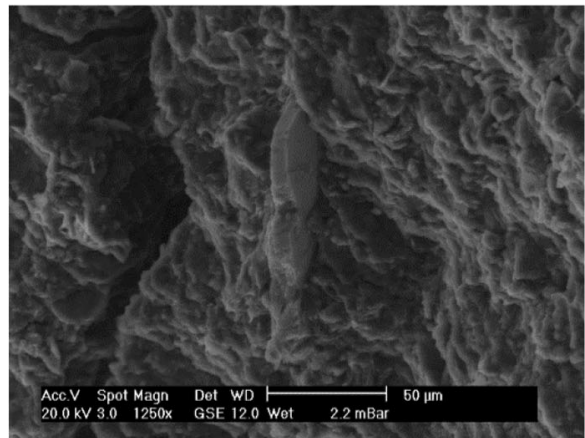

(a)

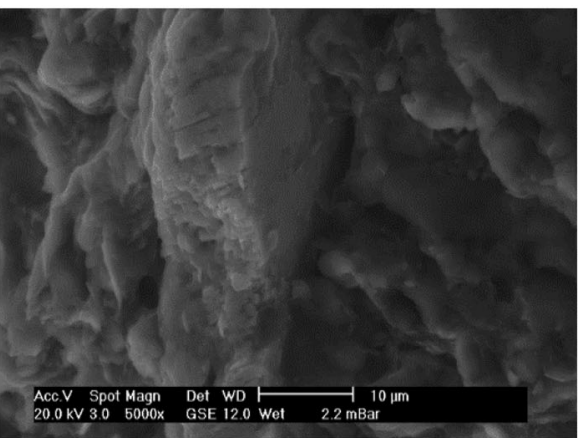

(b)

Fig. 5 ESEM micrographs showing the oriented fabric, fracture through the sample, and calcite crystal between clay grains and clay particles at magnification of: a $1250 x$; b 5000x

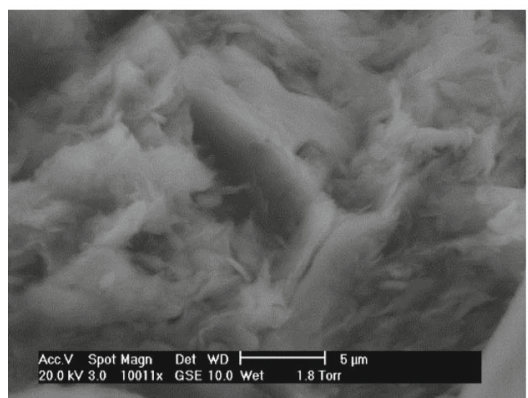

(a)

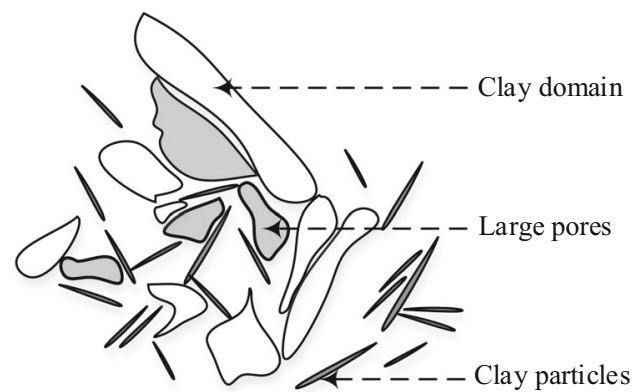

(b)

Fig. 6 ESEM micrograph: a soil fabric, b schematic diagram of particles and domains arrangements and presence of large pores in flocculated soil fabric

Isle of Sheppey, revealed the similarity in compositions of Sheppey LC with Ockenden LC, with differences being only in the relative proportions of some diagenetic minerals. The principal authigenic minerals in Sheppey LC are carbonates, apatite and pyrite. The fibrous calcite, present in Sheppey concretions, comprises a maximum of $5 \%$ total Magnesium ( $\mathrm{Mg}$ ), Manganese (Mn), and Iron (Fe). About $50 \%$ of the concretions comprise predominantly detrital clay minerals of illite and smectite, with the presence of a slight amount of coarsely crystalline authigenic kaolinite. Silt grains are predominantly 


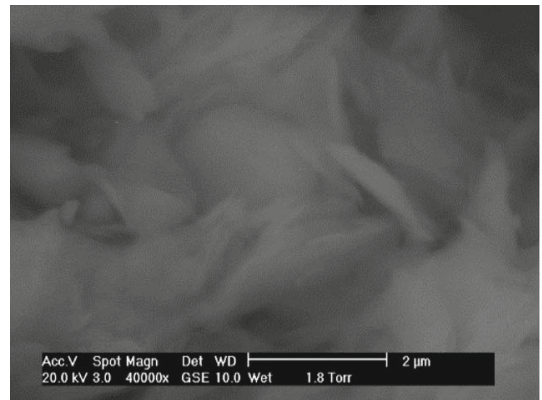

(a)

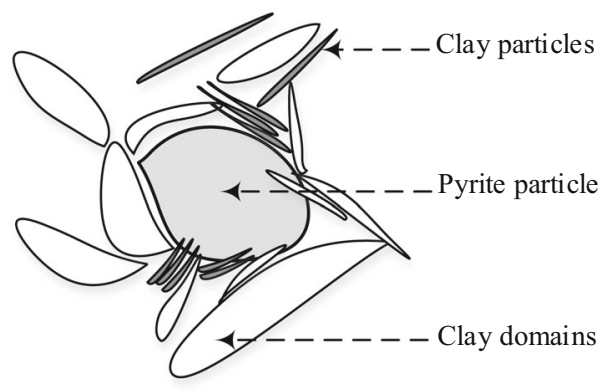

(b)

Fig. 7 Clay particles and domains around a pyrite particle: a ESEM micrograph, b schematic diagram

Fig. 8 ESEM micrographs showing the progressive drying of the clay sample

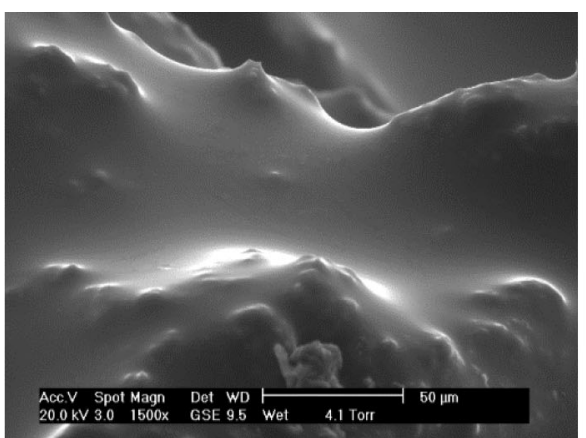

(a)

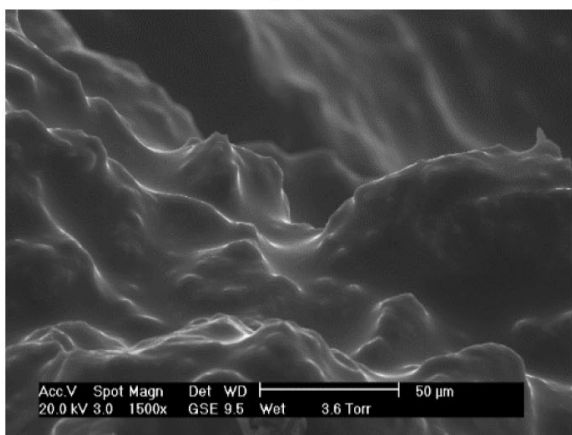

(c)

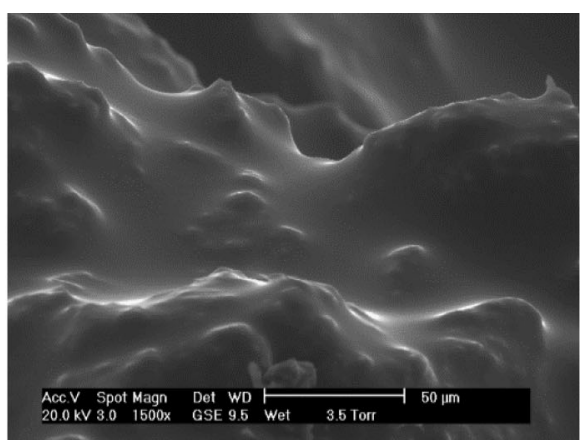

(b)

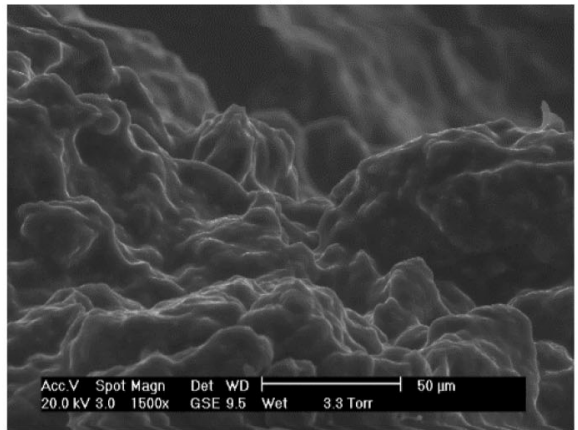

(d) quartz and K-feldspar. A clay/quartz ratio of 3.2:1 was also reported. Similar results were obtained from the EDX analysis carried out in this research, as shown in Fig. 9. The key petrographical characteristics of the sample are summarised in Table 1. It is observed that Silicon dioxide $\left(\mathrm{SiO}_{2}\right)$, Aluminium oxide $\left(\mathrm{Al}_{2} \mathrm{O}_{3}\right)$, Calcium carbonate $\left(\mathrm{CaCO}_{3}\right)$, and Iron disulphide $\left(\mathrm{FeS}_{2}\right)$ are predominant constituents of the samples. Calcium $(\mathrm{Ca})$ and Iron are the products of weathering of silicate minerals. Calcium carbonate precipitates are formed from the chemical interaction of Calcium and Carbon Dioxide $\left(\mathrm{CO}_{2}\right)$ molecules dissolved in sea water. Similarly, Iron reacts with Sulphur (S), resulting from rotting organic matter, and forms pyrite $\left(\mathrm{FeS}_{2}\right)$ (Gasparre 2005).

The waste acceptance criteria (WAC) testing was carried out by CET Structures Ltd on representative samples taken from the reservoir site to determine if the soil (waste) has any hazardous properties as per the Environment Agency's Hazardous Waste Technical Guidance WM2. The likely behaviour of waste in a landfill is assessed against WAC limits for granular waste acceptance at inert waste landfills, stable nonreactive hazardous landfills, and hazardous waste 

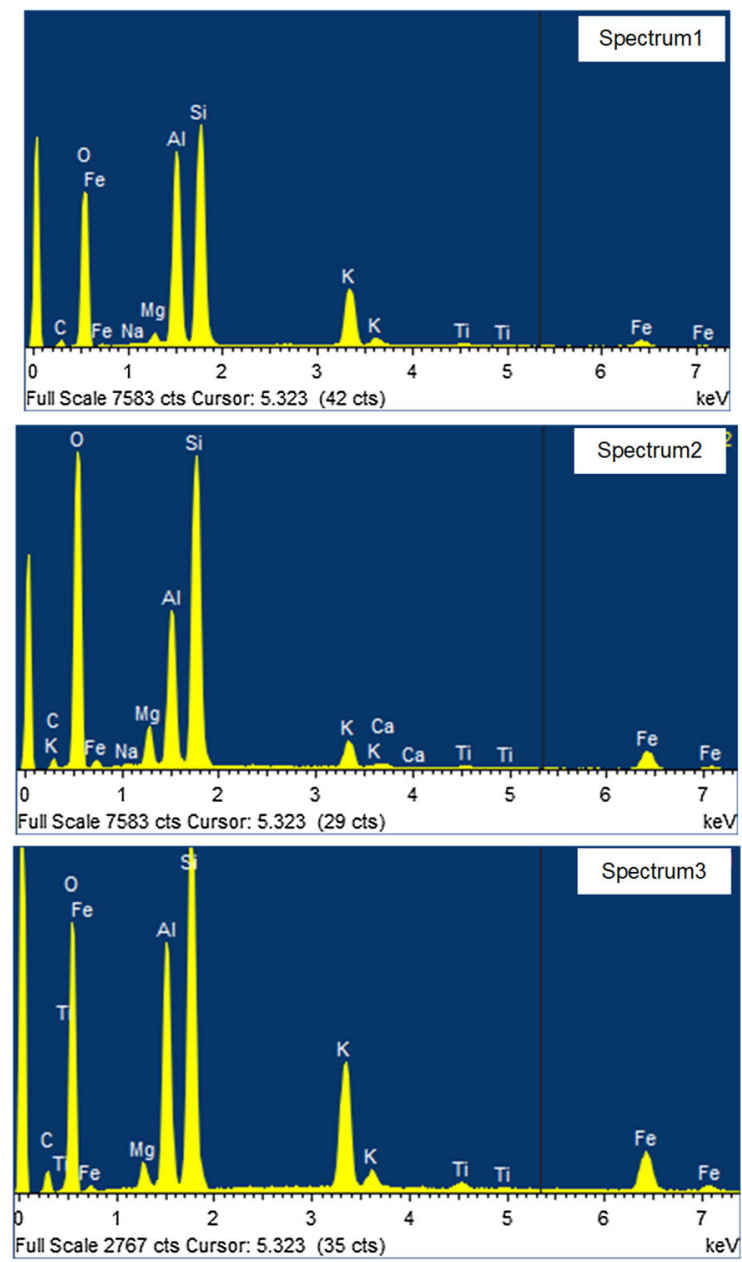

Fig. 9 The X-Ray spectra acquired from different points on the same sample landfills. These limits are based on total concentration limits for the organic components and $\mathrm{pH}$, as well as leachable components (Environment Agency 2013). The obtained results are summarised in Tables 2 and 3 . For all of the evaluated parameters, the obtained results from chemical analysis are below the set limits, except the values of $\mathrm{pH}$ and total dissolved solids (TDS) that lay above the WAC limits for inert waste landfill.

\section{Grain Size Analysis}

The particle size distribution (PSD) curve for natural samples was obtained from wet sieving and hydrometer sedimentation tests according to BS1377:Part2:1990. As shown in Fig. 10 and Table 4, the percentage by weight of fine grains (clay and very fine silt) appears to be larger for Sheppey LC in comparison with shallow depth T5 LC. Using GRADISTAT statistical package (Blott and Pye 2001), further grain size parameters such as sand, silt, and clay contents, texture, mean, mode, median, skewness, sorting, $\mathrm{D}_{10}, \mathrm{D}_{25}, \mathrm{D}_{50}, \mathrm{D}_{75}$, and $\mathrm{D}_{90}$ values were derived as shown in Table 4.

\section{Index Properties}

Laboratory determination of index parameters carried out according to BS1377:Part2:1990, confirmed a

Table 1 Average chemical composition (\% by weight) of Sheppey LC

\begin{tabular}{|c|c|c|c|c|c|c|c|c|c|c|c|}
\hline Spectrum & $\begin{array}{l}\mathrm{C} \\
\left(\mathrm{CaCO}_{3}\right)\end{array}$ & $\begin{array}{l}\mathrm{O} \\
\left(\mathrm{SiO}_{2}\right)\end{array}$ & $\begin{array}{l}\mathrm{Na} \\
\text { (Albite) }\end{array}$ & $\begin{array}{l}\mathrm{Mg} \\
(\mathrm{MgO})\end{array}$ & $\begin{array}{l}\mathrm{Al} \\
\left(\mathrm{Al}_{2} \mathrm{O}_{3}\right)\end{array}$ & $\begin{array}{l}\mathrm{Si} \\
\left(\mathrm{SiO}_{2}\right)\end{array}$ & $\begin{array}{l}\mathrm{K} \\
\text { (Feldespar) }\end{array}$ & $\begin{array}{l}\mathrm{Ca} \\
\text { (Wollastonite) }\end{array}$ & $\mathrm{Ti}$ & $\begin{array}{l}\mathrm{Fe} \\
\text { (Metal) }\end{array}$ & Total \\
\hline $\begin{array}{l}\text { Spectrum } \\
1\end{array}$ & 5.16 & 50.13 & 0.21 & 0.77 & 14.03 & 19.39 & 7.37 & 0.22 & 0.49 & 2.23 & 100.00 \\
\hline $\begin{array}{l}\text { Spectrum } \\
2\end{array}$ & 5.64 & 56.31 & 0.24 & 2.41 & 8.51 & 19.21 & 2.33 & 0.37 & 0.40 & 4.59 & 100.00 \\
\hline $\begin{array}{l}\text { Spectrum } \\
3\end{array}$ & 6.75 & 53.67 & 0.12 & 1.55 & 8.65 & 20.76 & 3.62 & 0.17 & 0.33 & 4.38 & 100.00 \\
\hline Mean & 5.85 & 53.37 & 0.19 & 1.57 & 10.40 & 19.79 & 4.44 & 0.25 & 0.41 & 3.73 & 100.00 \\
\hline $\begin{array}{l}\text { Std. } \\
\text { deviation }\end{array}$ & 0.81 & 3.10 & 0.06 & 0.82 & 3.15 & 0.85 & 2.62 & 0.10 & 0.08 & 1.31 & \\
\hline Max. & 6.75 & 56.31 & 0.24 & 2.41 & 14.03 & 20.76 & 7.37 & 0.37 & 0.49 & 4.59 & \\
\hline Min. & 5.16 & 50.13 & 0.12 & 0.77 & 8.51 & 19.21 & 2.33 & 0.17 & 0.33 & 2.23 & \\
\hline
\end{tabular}


Table 2 Criteria for granular waste acceptable at landfills-Organic components and $\mathrm{pH}$

\begin{tabular}{|c|c|c|c|c|c|}
\hline \multirow[t]{2}{*}{ Parameter } & \multirow[t]{2}{*}{ Unit } & \multirow[t]{2}{*}{ Result } & \multicolumn{3}{|l|}{ WAC limits } \\
\hline & & & Inert waste landfill & $\begin{array}{l}\text { Stable Non-reactive } \\
\text { hazardous landfill }\end{array}$ & $\begin{array}{l}\text { Hazardous } \\
\text { waste landfill }\end{array}$ \\
\hline Total organic carbon & $\%$ & $<1.0$ & 3 & 5 & 6 \\
\hline Loss on ignition & $\%$ & 5.2 & - & - & 10 \\
\hline BTEX $^{\mathrm{a}}$ (sum) & $\mathrm{mg} / \mathrm{kg}$ & $<0.3$ & 6 & - & - \\
\hline PCB's ${ }^{b}$ (7 congeners) & $\mathrm{mg} / \mathrm{kg}$ & $<0.03$ & 1 & - & - \\
\hline Mineral oil $>\mathrm{C} 10-\mathrm{C} 40$ & $\mathrm{mg} / \mathrm{kg}$ & $<16.1$ & 500 & - & - \\
\hline $\mathrm{PAH}^{\mathrm{c}}$ & $\mathrm{mg} / \mathrm{kg}$ & $<1.7$ & 100 & - & - \\
\hline $\mathrm{pH}$ & - & 7.7 & - & $>6$ & - \\
\hline
\end{tabular}

a-Volatile aromatic hydrocarbons benzene, toluene, ethylbenzene and xylenes

b-Polychlorinated biphenyls

c-Polycyclic aromatic hydrocarbons

range of $19-24 \%$ and $70-78 \%$ respectively for plastic limit $\left(w_{p}\right)$ and liquid limit $\left(w_{L}\right)$ indices. The upper band values are closely matched with $w_{p}=28 \%$ and $w_{L}=77 \%$ reported by Jardine et al. (2003) for Sheppey LC. Overall, the plastic limit of Sheppey LC at shallow depths appears to be less than shallow depth T5 LC with $w_{p}=29 \%$ for Unit C, whereas, the plasticity index for Sheppey LC $\left(I_{p}=52\right)$ is higher than Unit C T5 LC $\left(I_{p}=37\right)$. Based on the unified soil classification system (USCS), Sheppey LC is classified as clay of high plasticity $(\mathrm{CH})$. Based on BS1377:Part2:1990, the specific gravity $\left(G_{s}\right)$ was measured as 2.67 which is lower than the average value of 2.74 reported for Unit C T5 LC (Gasparre 2005).

\subsection{Permeability and Water Content}

The coefficient of vertical permeability $\left(k_{v}\right)$ was determined based on the constant head test in a triaxial cell (BS1377:Part6:1990). An undisturbed specimen with a diameter of $d=100 \mathrm{~mm}$, height of $L=99 \mathrm{~mm}$, initial bulk density of $\rho_{b}=1.894 \mathrm{Mg} / \mathrm{m}^{3}$, and initial moisture content of $w_{0}=32.2 \%$, was saturated for 7 days and then consolidated for 3 days under an effective stress of $100 \mathrm{kPa}$. A constant hydraulic gradient of $i=20 \mathrm{kPa}$ was applied across the specimen, and the mean rate of flow of water through the soil specimen $(Q)$ was measured (in $\mathrm{mL} / \mathrm{min}$ ). The value of $k_{v}$ at $20^{\circ} \mathrm{C}$ was calculated as $2.5 \times 10^{-10} \mathrm{~ms}^{-1}$ using the Eq. 1; $k_{v}=\frac{1.63 Q L}{A\left(i-p_{c}\right)} \times R_{t} \times 10^{-4}$

where $A$ is the specimen's cross sectional area (in $\mathrm{mm}^{2}$ ), $p_{c}$ is the pressure loss in the system (in $\mathrm{kPa}$ ) for the rate of flow $q$, and $R_{t}$ is the temperature correction factor for the viscosity of water.

The in-situ water content was measured in a range of 29-35\% based on oven drying method (BS1377:Part2:1990). The Sheppey LC appears to be wetter in comparison with T5 LC having an average in-situ water content of $24-27 \%$ at about $7 \mathrm{~m}$ depth (Unit C) as reported in Hight et al. (2003) and Gasparre (2005). The moisture condition value (MCV) at the natural moisture content was also measured as 13.2 based on the method described in BS1377:Part4:1990. This parameter is often used for assessment of the condition of a soil, for example, its suitability for use in earthwork construction.

\section{One-Dimensional Compression Behaviour}

Figure 11a presents a comparison of the normalised compression curves for Sheppey LC and the natural LC from Unit C of T5 site. As the plasticity of the LC deposits increases from west to east of the London basin (Hight et al. 2007), the compression curve for Sheppey specimen was expected to lay below the compression curve for T5 specimen. It is observed that the T5 specimen is less compressible than the Sheppey specimen, mainly due to its lower plasticity index 
Table 3 Criteria for granular waste acceptable at landfills-Leachate

\begin{tabular}{|c|c|c|c|c|c|}
\hline \multirow[t]{2}{*}{ Parameter } & \multirow[t]{2}{*}{ Unit } & \multirow[t]{2}{*}{ Result } & \multicolumn{3}{|l|}{ WAC limits } \\
\hline & & & $\begin{array}{l}\text { Inert waste } \\
\text { landfill }\end{array}$ & $\begin{array}{l}\text { Stable non-reactive } \\
\text { hazardous landfill }\end{array}$ & $\begin{array}{l}\text { Hazardous } \\
\text { waste landfill }\end{array}$ \\
\hline As (arsenic) & $\mathrm{mg} / \mathrm{kg}$ & $<0.01$ & 0.5 & 2 & 25 \\
\hline $\mathrm{Ba}$ (barium) & $\mathrm{mg} / \mathrm{kg}$ & $<0.02$ & 20 & 100 & 300 \\
\hline Cd (cadmium) & $\mathrm{mg} / \mathrm{kg}$ & $<0.01$ & 0.04 & 1 & 5 \\
\hline $\mathrm{Cr}$ (chromium (total)) & $\mathrm{mg} / \mathrm{kg}$ & $<0.01$ & 0.5 & 10 & 70 \\
\hline $\mathrm{Cu}$ (copper) & $\mathrm{mg} / \mathrm{kg}$ & $<0.04$ & 2 & 50 & 100 \\
\hline $\mathrm{Hg}$ (mercury) & $\mathrm{mg} / \mathrm{kg}$ & $<0.01$ & 0.01 & 0.2 & 2 \\
\hline Mo (molybdenum) & $\mathrm{mg} / \mathrm{kg}$ & $<0.01$ & 0.5 & 10.0 & 30 \\
\hline Ni (nickel) & $\mathrm{mg} / \mathrm{kg}$ & $<0.01$ & 0.4 & 10.0 & 40 \\
\hline $\mathrm{Pb}$ (lead) & $\mathrm{mg} / \mathrm{kg}$ & $<0.04$ & 0.5 & 10.0 & 50 \\
\hline $\mathrm{Sb}$ (antimony) & $\mathrm{mg} / \mathrm{kg}$ & $<0.01$ & 0.06 & 0.7 & 5 \\
\hline Se (selenium) & $\mathrm{mg} / \mathrm{kg}$ & 0.04 & 0.1 & 0.5 & 7 \\
\hline Zn (zinc) & $\mathrm{mg} / \mathrm{kg}$ & $<0.04$ & 4 & 50 & 200 \\
\hline $\mathrm{Cl}$ (chloride) & $\mathrm{mg} / \mathrm{kg}$ & 249 & 800 & 15,000 & 25,000 \\
\hline F (fluoride) & $\mathrm{mg} / \mathrm{kg}$ & 1 & 10 & 150 & 500 \\
\hline $\mathrm{SO}_{4}$ (sulphate) & $\mathrm{mg} / \mathrm{kg}$ & 836 & 1000 & 20,000 & 50,000 \\
\hline Total dissolved solids (TDS) + & $\mathrm{mg} / \mathrm{kg}$ & 4804 & 4000 & 60,000 & 100,000 \\
\hline Phenol index & $\mathrm{mg} / \mathrm{kg}$ & $<0.4$ & 1 & - & - \\
\hline Dissolved organic carbon & $\mathrm{mg} / \mathrm{kg}$ & 10 & 500 & 800 & 1000 \\
\hline
\end{tabular}

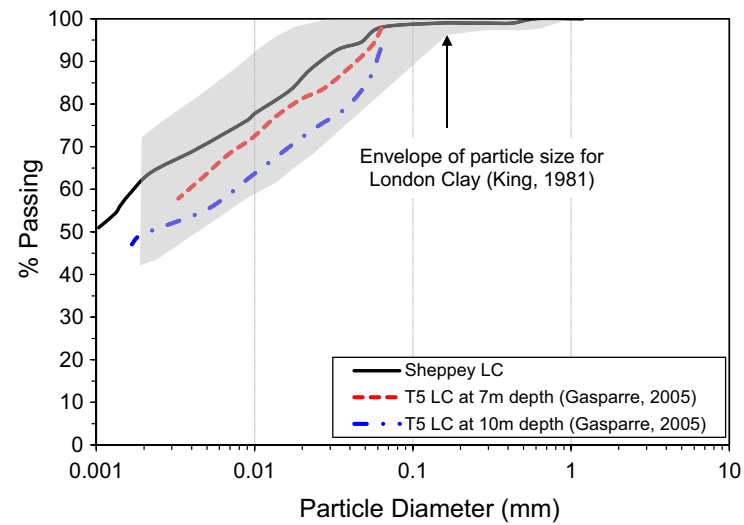

Fig. 10 Particle size distribution curve

$\left(I_{p}=37\right)$ and initial water content $\left(w_{0}=24 \%\right)$. Average compression index $\left(C_{c}\right)$ and swelling index $\left(C_{s}\right)$ values of respectively 0.22 and 0.10 were obtained from the compression tests on intact Sheppey specimens having an average initial void ratio of $e_{0}=0.85$. Similar values are derived from the compression curve of the intact T5 specimen.
It is worth mentioning here that soil structure can be disturbed during the process of sampling, transport, and storage, modifying initial properties of the soil sample. Among various soils sampling techniques, block sampling (employed in this study) is considered as a suitable method, which if performed adequately can produce 'class 1 ' quality samples of natural clays with minimum to negligible level of disturbance to the soil structure. Using this method, soil properties such as particle size, water content, density, density index, permeability, compressibility, and shear strength can remain unchanged (BS-EN-1997:2 2007). Furthermore, block samples allow for reliable determination of porosity. Accordingly, the laboratory void ratio values obtained from block samples are, with good accuracy, comparable to the field void ratio.

Figure $11 \mathrm{~b}$ presents a comparison of the normalised compression curves for reconstituted Sheppey LC and the reconstituted T5 LC. The reconstituted specimens were obtained from consolidation of soil slurry in a Perspex consolidometer under a vertical stress of $80 \mathrm{kPa}$ for a duration of 5 days. Average $C_{c}{ }_{c}$ and $C^{*}{ }_{s}$ values of respectively 0.38 and 0.13 were 
Table 4 Statistical and grain size parameters

\begin{tabular}{|c|c|c|c|c|}
\hline \multirow{2}{*}{$\begin{array}{l}\text { Soil } \\
\text { Parameter }\end{array}$} & \multicolumn{2}{|c|}{ Sheppey LC } & \multicolumn{2}{|c|}{ Heathrow T5 LC } \\
\hline & $\mu \mathrm{m}$ & $\phi$ & $\mu \mathrm{m}$ & $\phi$ \\
\hline Mode 1 & 1.350 & 9.534 & 1.790 & 9.129 \\
\hline Mode 2 & 9.550 & 6.713 & 7.740 & 7.031 \\
\hline Mode 3 & 55.000 & 4.200 & 57.580 & 4.123 \\
\hline $\mathrm{D}_{10}$ & 1.374 & 4.204 & 1.828 & 4.583 \\
\hline Median or $\mathrm{D}_{50}$ & 4.548 & 7.780 & 8.150 & 6.939 \\
\hline $\mathrm{D}_{90}$ & 54.250 & 9.507 & 41.730 & 9.095 \\
\hline$\left(\mathrm{D}_{90} / \mathrm{D}_{10}\right)$ & 39.490 & 2.261 & 22.830 & 1.985 \\
\hline$\left(\mathrm{D}_{90}-\mathrm{D}_{10}\right)$ & 52.880 & 5.303 & 39.910 & 4.513 \\
\hline$\left(\mathrm{D}_{75} / \mathrm{D}_{25}\right)$ & 12.950 & 1.658 & 5.712 & 1.448 \\
\hline$\left(\mathrm{D}_{75}-\mathrm{D}_{25}\right)$ & 18.860 & 3.695 & 16.810 & 2.514 \\
\hline Mean $(\bar{x})^{*}$ & $6.374^{\mathrm{a}}$ & $7.294^{\mathrm{b}}$ & 8.700 & 6.845 \\
\hline Sorting $(\sigma)^{*}$ & $4.179^{\mathrm{a}}$ & $2.063^{\mathrm{b}}$ & 2.996 & 1.583 \\
\hline Skewness $(S k)^{*}$ & $0.538^{\mathrm{a}}$ & $-0.538^{b}$ & 0.193 & -0.193 \\
\hline Kurtosis $(K)^{*}$ & $2.060^{\mathrm{a}}$ & $2.060^{\mathrm{b}}$ & 2.059 & 2.059 \\
\hline Mean $(\bar{x})^{* *}$ & $6.827^{\mathrm{a}}$ & $7.194^{\mathrm{b}}$ & 7.963 & 6.973 \\
\hline Sorting $(\sigma)^{* *}$ & $4.286^{\mathrm{a}}$ & $2.100^{\mathrm{b}}$ & 3.302 & 1.723 \\
\hline Skewness $(S k)^{* *}$ & $0.350^{\mathrm{a}}$ & $-0.350^{\mathrm{b}}$ & 0.041 & -0.041 \\
\hline Kurtosis $(K)^{* *}$ & $0.607^{\mathrm{a}}$ & $0.607^{\mathrm{b}}$ & 0.811 & 0.811 \\
\hline$\%$ Coarse Sand & 0.2 & & 0.0 & \\
\hline$\%$ Medium Sand & 0.6 & & 0.0 & \\
\hline$\%$ Fine Sand & 0.6 & & 0.4 & \\
\hline$\%$ Very Fine Sand & 0.9 & & 1.6 & \\
\hline \% Very Coarse Silt & 18.4 & & 13.3 & \\
\hline$\%$ Coarse Silt & 8.6 & & 16.6 & \\
\hline \% Medium Silt & 14.4 & & 19.7 & \\
\hline$\%$ Fine Silt & 8.5 & & 21.9 & \\
\hline$\%$ Very Fine Silt & 13.9 & & 11.3 & \\
\hline$\%$ Clay & 33.9 & & 15.2 & \\
\hline
\end{tabular}

*Method of moments (Krumbein and Pettijohn 1938)

**Folk and Ward (1957) Method

${ }^{\mathrm{a}}$ Geometric values, ${ }^{\mathrm{b}}$ Logarithmic values

obtained from reconstituted specimens with $e_{0}=0.93$. The reconstituted T5 specimen, with average $C_{c}^{*}$ and $C^{*}{ }_{s}$ values of respectively 0.39 and 0.15 (Gasparre, 2005), exhibits higher compressibility in comparison with the reconstituted Sheppey specimen.

As reported in Rezania et al. (2019), the maximum value of creep index $\left(C_{\alpha}\right)$ for Sheppey LC falls approximately in the range of $0.007-0.008$ and $0.012-0.013$ respectively for intact and reconstituted specimens, the latter being comparable with the

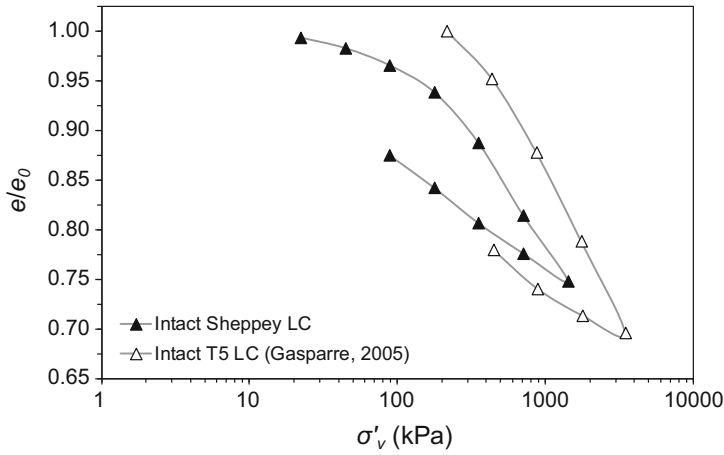

(a)

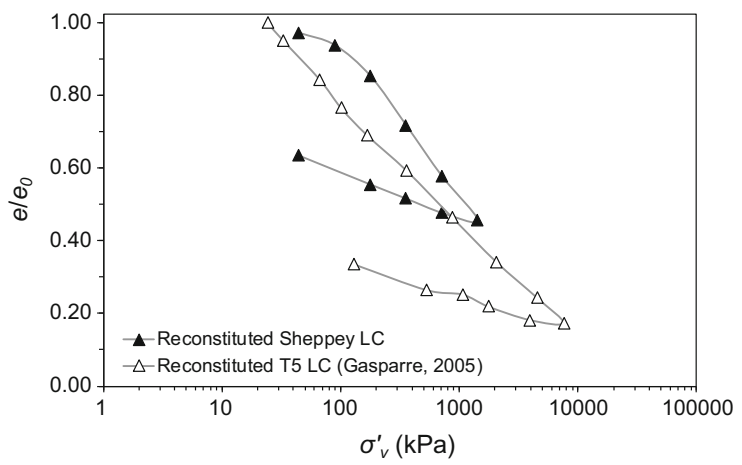

(b)

Fig. 11 Comparison of the compression curves for Sheppey LC and T5 LC a intact specimens, $\mathbf{b}$ reconstituted specimens

average value of $C_{\alpha}=0.016$ reported by Sorensen (2006) for reconstituted T5 LC. The ratio $\alpha=C_{\alpha} / C_{c}$ for Sheppey LC falls approximately in the range of 0.015-0.046 and 0.023-0.037 respectively for intact and reconstituted specimens. The maximum values of $\alpha$ occur at stress levels in a range of 1-2 times yield vertical net stress $\left(\sigma_{p}\right)$, for both intact and reconstituted specimens.

A series of drained constant rate of strain (CRS) compression-relaxation tests was performed on reconstituted Sheppey LC using an innovative CRS oedometer cell (Bagheri et al. 2020) equipped with two high-capacity tensiometers (Bagheri et al. 2018) for monitoring pore-water pressure evolutions, in order to evaluate the rate-dependent and stress-relaxation responses. Specimens of different initial water contents (and hence different initial suction $s_{0}$ ) were loaded to a certain stress level $\left(\sigma_{0}=3450 \mathrm{kPa}\right)$, then allowed for stress relaxation at zero rate of axial displacement for a minimum time period of $210 \mathrm{~h}$. Table 5 outlines the details of these tests and Fig. 12 presents the soil water retention curve (SWRC) of the 
reconstituted soil sample. The SWRC was obtained using HCT technique and following the dynamic method as described in Bagheri (2018). Figure 13 presents the 1D compression behaviour of the specimens loaded at two different strain rates of $\varepsilon_{v 1}=4.8$ $\times 10^{-7} \mathrm{~s}^{-1}$ and $\dot{\varepsilon_{v 2}}=2.4 \times 10^{-6} \mathrm{~s}^{-1}$, where $\dot{\varepsilon_{v 2}}=5 \dot{\varepsilon_{v 1}}$, in axial strain $\left(\varepsilon_{a}\right)$ versus vertical net stress $\left(\sigma_{v n e t}\right)$ space. The values of the yield vertical net stress $\left(\sigma_{p}\right)$ were found to decrease exponentially with increase of $w_{0}$ for both selected strain rates as shown in Fig. 14.

The values of the coefficient of stress relaxation $\left(R_{\alpha}\right)$, being the rate of change of $\sigma_{v n e t}$ with time $(t)$ at zero strain rate in $\log -\log$ space, fell within a range of 0.011-0.019 and 0.017-0.029, respectively for fast and slow strain rates (Bagheri et al. 2019), the latter corresponds well with the values of $\alpha$ ratio of 0.023-0.030 obtained from multi-staged loading

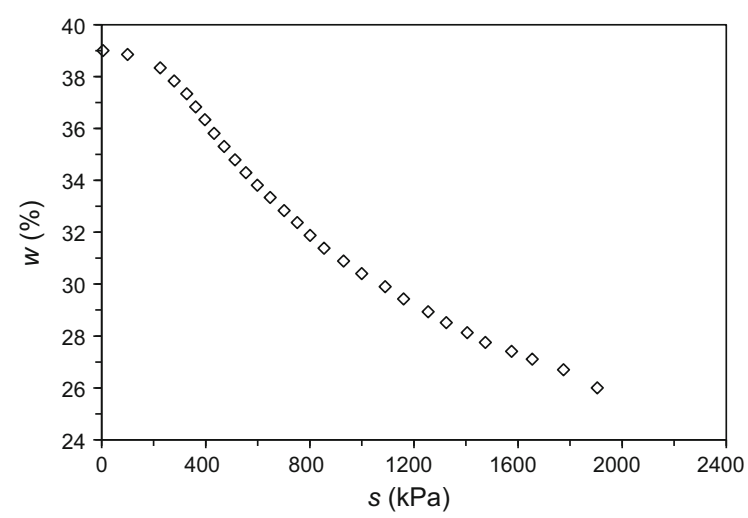

Fig. 12 SWRC for reconstituted soil sample (data from Bagheri 2018) oedometer tests on reconstituted Sheppey LC at different initial water contents reported in Bagheri (2018).

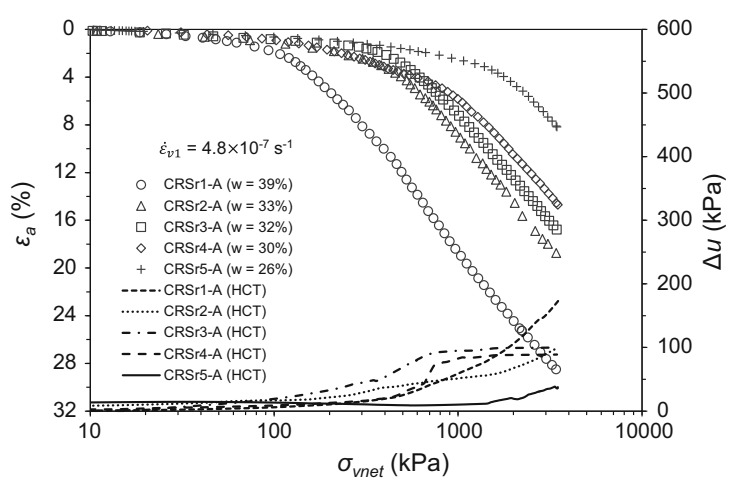

(a)

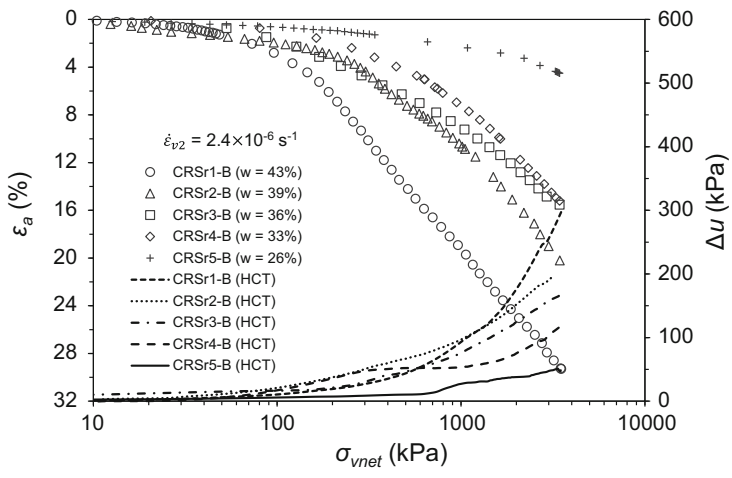

(b)

Fig. 13 CRS compression curves at different initial water contents: a $\dot{\varepsilon}_{v 1}=4.8 \times 10^{-7} \mathrm{~s}^{-1}$, b $\dot{\varepsilon}_{v 2}=2.4 \times 10^{-6} \mathrm{~s}^{-1}$ (replotted from Bagheri et al. 2019)
Table 5 Details of the CRS tests (data from Bagheri et al. 2019) r-reconstituted; A and Bstrain rates

\begin{tabular}{llllll}
\hline Test ID & $w_{0}[\%]$ & $s_{0}[\mathrm{kPa}]$ & $\dot{\varepsilon}_{v}\left[\mathrm{~s}^{-1}\right]$ & $\sigma_{p}[\mathrm{kPa}]$ & $\sigma_{0}[\mathrm{kPa}]$ \\
\hline CRSr1-A & 39 & 0 & $4.8 \times 10^{-7}$ & 157 & 3451 \\
CRSr2-A & 33 & 701 & $4.8 \times 10^{-7}$ & 436 & 3422 \\
CRSr3-A & 32 & 802 & $4.8 \times 10^{-7}$ & 539 & 3440 \\
CRSr4-A & 30 & 1045 & $4.8 \times 10^{-7}$ & 676 & 3448 \\
CRSr5-A & 26 & 1905 & $4.8 \times 10^{-7}$ & 1493 & 3459 \\
CRSr1-B & 43 & 0 & $2.4 \times 10^{-6}$ & 108 & 3488 \\
CRSr2-B & 39 & 0 & $2.4 \times 10^{-6}$ & 227 & 3451 \\
CRSr3-B & 36 & 433 & $2.4 \times 10^{-6}$ & 288 & 3445 \\
CRSr4-B & 33 & 701 & $2.4 \times 10^{-6}$ & 655 & 3442 \\
CRSr5-B & 26 & 1905 & $2.4 \times 10^{-6}$ & 1551 & 3444 \\
\hline
\end{tabular}




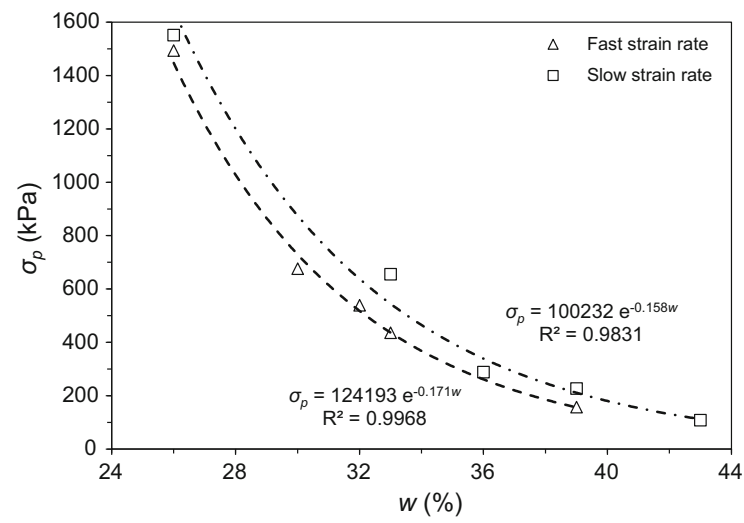

Fig. 14 Variation of $\sigma_{p}$ with initial water content (data from Bagheri et al. 2019)

\section{Conclusions}

Some characteristics of LC from New Hook farm in the Isle of Sheppey were discussed and compared with shallow depth (Unit C) T5 LC. The following conclusions can be drawn;

- The ESEM analyses showed that similar to Unit C T5 LC, Sheppey LC has an open structure containing a large proportion of silt-sized grains which is consistent with PSD of this soil.

- This soil fabric for Sheppey LC is comparable with flocculated cardhouse fabric for T5 LC at shallow depths.

- Silicon dioxide $\left(\mathrm{SiO}_{2}\right)$, Aluminium oxide $\left(\mathrm{Al}_{2} \mathrm{O}_{3}\right)$, Calcium carbonate $\left(\mathrm{CaCO}_{3}\right)$, and Iron disulphide $\left(\mathrm{FeS}_{2}\right)$ are predominant constituents of the Sheppey LC.

- The Sheppey LC at shallow depths appears to be wetter and more plastic than shallow depth T5 LC.

- The Sheppey LC is more compressible than the Unit C T5 LC in undisturbed state, and less compressible in reconstituted state.

Open Access This article is licensed under a Creative Commons Attribution 4.0 International License, which permits use, sharing, adaptation, distribution and reproduction in any medium or format, as long as you give appropriate credit to the original author(s) and the source, provide a link to the Creative Commons licence, and indicate if changes were made. The images or other third party material in this article are included in the article's Creative Commons licence, unless indicated otherwise in a credit line to the material. If material is not included in the article's Creative Commons licence and your intended use is not permitted by statutory regulation or exceeds the permitted use, you will need to obtain permission directly from the copyright holder. To view a copy of this licence, visit http://creativecommons.org/licenses/by/4.0/.

\section{References}

Aldiss DT (2014) The stratigraphical framework for the Palaeogene successions of the London Basin, UK. British Geological Survey Open Report OR/14/008

Bagheri M (2018) Experimental investigation of the time- and rate-dependent behaviour of unsaturated clays. Ph.D. thesis, University of Nottingham

Bagheri M, Mousavi Nezhad M, Rezania M (2020) A CRS oedometer cell for unsaturated and non-isothermal tests. Geotech Test J 43(1):20180204. https://doi.org/10.1520/ GTJ20180204

Bagheri M, Rezania M, Mousavi Nezhad M (2018) Cavitation in high-capacity tensiometers: effect of water reservoir surface roughness. Geotech Res 5(2):81-95. https://doi.org/ 10.1680/jgere.17.00016

Bagheri M, Rezania M, Mousavi Nezhad M (2019) Rate-dependency and stress relaxation of unsaturated clays. Int $\mathbf{J}$ Geomech 19(12):04019128. https://doi.org/10.1061/ (ASCE)GM.1943-5622.0001507

Blott SJ, Pye K (2001) GRADISTAT: a grain size distribution and statistics package for the analysis of unconsolidated sediments. Earth Surf Processes Landf 26:1237-1248. https://doi.org/10.1002/esp.261

BS1377 (1990) Methods of test for soils for engineering purposes, Part 2: Classification tests

BS1377 (1990) Methods of test for soils for engineering purposes, Part 4: Compaction related tests

BS-EN-1997:2 (2007) Eurocode 7-Geotechnical design-Part 2: Ground investigation and testing. London: British Satandards Institution

Burland JB (1990) On the compressibility and shear strength of natural clays. Géotechnique 40:329-378

Burnett AD, Fookes PG (1974) A regional engineering geological study of the London Clay in the London and Hampshire basins. Q J Eng Geol Hydrogeol 7:257-295. https://doi.org/10.1144/GSL.QJEG.1974.007.03.02

Environemnt Agency (2013) Waste sampling and testing for disposal to landfill, Report No. EBPRI 11507B

Folk RL, Ward WC (1957) Brazos river bar: a study in the significance of grain size parameters. J Sediment Res 27:3-26

Gasparre A (2005) Advanced labortory characterisation of London Clay. Ph.D. Thesis, University of London

Helsey M, Codd F (2014) Aviation: proposals for an airport in the Thames Estuary, 1945-2014. House of commons library, standard note SN/BT/4920, pp. 70

Hight DW, Jardine RJ (1993) Small strain stiffness and strength characteristics of hard London Clay Tertiary clays. International symposium on hard soils-soft rocks, Anagnostopoulos et al. (eds), Athens, Greece. Rotterdam: Balkema, 522-533

Hight DW, Gasparre A, Nishimura S, Minh NA, Jardine RJ, Coop MR (2007) Characteristics of the London Clay from the Terminal 5 site at Heathrow Airport. Géotechnique $57: 3-18$ 
Hight DW, Higgins KG, Jardine RJ, Potts DM, Pickles AR., De Moor EKD, Nyirenda ZM (1993) Predicted and measured tunnel distortions associated with construction of waterloo international terminal. Predictive soil mechanics: proceedings of the worth memorial symposium, St Catherine's College, Oxford, Houlsby GT, Schofield AN (eds), Thomas Telford, London, 317-338

Hight DW, Mcmillan F, Powell JJM, Jardine,RJ, Allenou CP (2003) Some characteristics of London Clay. In: Proceedings of the 1st international workshop on characterisation and engineering properties of natural soils, Singapore, Tan TS, Phoon KK, Hight KW, Leroueil S, Balkema AA (eds), 851-907

Huggett JM (1994) Diagenesis of mudrocks and concretions from the London clay formation in the London basin. Clay Miner 29:693-707

Jardine RJ, Smith PR, Nicholson DP (2003) Properties of the soft Holocene Thames Estuary Clay from Queenborough, Kent. In: Proceedings of the 1st International workshop on characterisation and engineering properties of natural soils, Paris, Tan TS, Phoon KK, Hight DW, Leroueil S, Balkema AA (eds), 599-643
Jardine RJ (1985) Investigations of pile-soil behaviour, with special reference to the foundations of offshore structures. $\mathrm{PhD}$ Thesis, University of London (Imperial College).

King C (1981) The stratigraphy of the London Clay and associated deposits. Tertiary Research Special Paper, Backhuys, Rotterdam

Rezania M, Bagheri M, Mousavi Nezhad M (2020) Creep and consolidation of a stiff clay under saturated and unsaturated conditions. Can Geotech J 57(5):728-741

Skempton AW, Schuster FRS, Petley DJ (1969) Joints and fissures in the London Clay at Wraysbury and Edgware. Géotechnique 19:205-217

Smith PR (1992) The properties of natural high compressibility clays with particular reference to construction on soft ground. PhD Thesis, University of London (Imperial College)

Sorensen KK (2006) Influence of viscosity and ageing on the behaviour of clays. Ph.D. Thesis, University College London

Publisher's Note Springer Nature remains neutral with regard to jurisdictional claims in published maps and institutional affiliations. 